\title{
Some aspects of thecal and granulosa cell function during follicular development in the bovine ovary
}

\author{
K. P. McNatty, D. A. Heath, K. M. Henderson, S. Lun, P. R. Hurst*, \\ L. M. Ellis*, G. W. Montgomeryt, L. Morrison and D. C. Thurley
}

Wallaceville Animal Research Centre, Research Division, Ministry of Agriculture and Fisheries, Private Bag, Upper Hutt, New Zealand; *Department of Anatomy, Medical School, University of Otago, Dunedin, New Zealand; and †Invermay Agricultural Research Centre, Ministry of Agriculture and Fisheries, Private Bag, Mosgiel, New Zealand

\begin{abstract}
Summary. The patterns of ovarian follicular development and the steroidogenic properties of individual follicles ( $\geqslant 2 \mathrm{~mm}$ diam.) were assessed in Angus cows from Day -5 until Day +1 of the oestrous cycle (oestrus = Day 0 ). Individual follicles were judged to be healthy or atretic using a new classification system incorporating assessments of thecal vascularity and colour, the number of granulosa cells, the presence or absence of debris in follicular fluid and the status of the oocyte.

The results suggest that the theca interna of small antral follicles ( $<5 \mathrm{~mm}$ diam.) responds to $\mathrm{LH}$ and synthesizes androstenedione before the granulosa cells develop an appreciable ability to metabolize androgen to oestrogen. Regardless of follicle size, the output of thecal androstenedione per unit mass of tissue remained unchanged in healthy but not in atretic follicles. On a per cell basis, aromatase activity increased in granulosa cells from healthy but not from atretic follicles with increasing follicle size. Peak levels of aromatizing activity were consistently observed in dominant oestrogenenriched follicles on Day 0 although similar activity was also observed in some healthy follicles ( $\geqslant 8 \mathrm{~mm}$ diam.) on other days of the cycle. Early atresia in bovine follicles was characterized by an absence or lowering of aromatase activity in granulosa cells which always preceded any reduction in the thecal steroidogenic response to $\mathrm{LH}$.

It was estimated that between 20 and 60 antral follicles ( $\geqslant 2 \mathrm{~mm}$ diam.) per cow may respond to $\mathrm{LH}$ by synthesizing androgen whereas only 1-3 follicles ( $>5 \mathrm{~mm}$ diam.) have granulosa cells capable of metabolizing androstenedione or testosterone to oestradiol.
\end{abstract}

\section{Introduction}

It is generally accepted that bovine antral follicles grow and regress continuously throughout the oestrous cycle (Rajakoski, 1960; Donaldson \& Hansel, 1965; Erickson, 1966; Priedkalns, Weber \& Zemjanis, 1968). It has been estimated that a bovine follicle takes about 22 days to grow from $0 \cdot 4$ $\mathrm{mm}$ (i.e. early antral) to $10 \mathrm{~mm}$ (i.e. preovulatory size) in diameter, and more than 4 days to enlarge from $5 \mathrm{~mm}$ to preovulatory size (Scaramuzzi, Turnbull \& Nancarrow, 1980; Staigmiller \& England, 1982). From Day 4 of the oestrous cycle until ovulation there is usually one large follicle $(\geqslant 8 \mathrm{~mm}$ diam.) present every day (Rajakoski, 1960; Choudary, Gier \& Marion, 1968; Ireland, Coulson \& Murphree, 1979; Matton, Adelakoun, Couture \& Dufour, 1981; Ireland \& Roche, 1983). From histological criteria it is thought that the number of non-atretic follicles $>5.0 \mathrm{~mm}$ in diameter is low ( $\leqslant 3$ per cow) due to a high incidence of atresia in follicles enlarging from 2 to $5 \mathrm{~mm}$ in diameter (Rajakoski, 1960; Marion, Gier \& Choudary, 1968; Scaramuzzi et al., 1980). 
Androstenedione, testosterone and oestradiol are major secretory products of bovine follicles and their concentrations in peripheral plasma fluctuate markedly, and often asynchronously, both within days and between each day of the oestrous cycle (Dobson \& Dean, 1974; Lemon \& Saumande, 1974; Peterson, Fairclough, Payne \& Smith, 1975; Peterson, Fairclough \& Smith, 1978; Wise, Caton, Thatcher, Lehrer \& Fields, 1982). However, it has been difficult to extrapolate from hormone concentrations in peripheral plasma, the degree of follicular activity within the ovary. This is in part due to the fact that the relationship between the health of a follicle and its potential to synthesize steroids is poorly understood (Merz, Hauser \& England, 1981; Kruip \& Dieleman, 1982). Nevertheless, it is well established that large healthy ( $\geqslant 8 \mathrm{~mm}$ diam.) and/or preovulatory bovine follicles may synthesize large quantities of oestrogen (Short, 1962; Lunaas, 1964; England, Karavolas, Hauser \& Casida, 1973; Merz et al., 1981; Staigmiller, England, Webb, Short \& Bellows, 1982; Kruip \& Dieleman, 1982). For optimal oestradiol biosynthesis it is thought that a functional interaction between theca interna and granulosa cells is required with the two key variables being the amount of $\mathrm{LH}$-induced androstenedione or testosterone synthesized by the theca interna cells and the level of aromatase activity in granulosa cells (Hillier, 1981; McNatty et al., 1984a).

The objectives of this study were to determine (1) the degree of antral follicle development $(\geqslant 2$ mm diam.) from Day -5 until Day +1 of the oestrous cycle (oestrus = Day 0 ) and (2) the LH responsiveness of theca interna cells and amount of extant (or residual) aromatase activity in granulosa cells from healthy and atretic follicles.

\section{Materials and Methods}

Animals, blood sampling and recovery of ovaries. Thirty-three Angus cows aged 2-8 years (mean $4 \cdot 7$ years) were studied. Six animals were parous and 27 nulliparous. These animals were grazed on open pasture with a vasectomized bull and examined twice daily for oestrous activity. The mean oestrous cycle length ( $20.6 \pm 0.2$ days) in all 33 cows was determined from $7 \pm 0.5$ (s.e.m., $n=33$ ) consecutive oestrous cycles. For each cow the mean \pm s.e.m. coefficient of variability with respect to cycle length was $8.4 \pm 0.9 \%(n=33)$. After monitoring oestrous cycle activity, 10 of the cows were slaughtered on a known day of the oestrous cycle at a local slaughterhouse, and the ovaries recovered within 30 min of slaughter. The remaining 23 animals underwent ovariectomy on a known day of the oestrous cycle at the Wallaceville Animal Research Centre, after blood had first been obtained from the jugular and ovarian veins $(\sim 20 \mathrm{ml} / \mathrm{per}$ vein/cow $)$ of most animals. Ovariectomy and blood sampling was performed while the animals were under thiopentone sodium anaesthesia (Intraval; May and Baker, New Zealand). The ovaries were obtained within $1 \mathrm{~h}$ of induction of anaesthesia. All blood samples were collected into heparinized centrifuge tubes and centrifuged at $4000 \mathrm{~g}$ for $30 \mathrm{~min}$ at $6^{\circ} \mathrm{C}$ within $1 \mathrm{~h}$ of collection. Aliquots of the plasma were frozen to $-20^{\circ} \mathrm{C}$ for subsequent hormone determinations.

From all cows, the ovaries were collected into chilled Medium A (Medium 199 containing Earle's salts, L-glutamine (0.1 g/1), Hepes buffer (20 mmol/1) (Gibco, Santa Clara, CA, U.S.A.) and $0.1 \%$ BSA (w/v, fraction V, Sigma Chemical Co., St Louis, MO, U.S.A.).

Ovarian studies. Excised ovaries were weighed, and their gross morphology recorded. All individual antral follicles ( $\geqslant 2 \mathrm{~mm}$ diam.) and corpora lutea were dissected free of extraneous tissue under a stereomicroscope and their diameters recorded to the nearest $0.5 \mathrm{~mm}$. Dissection procedures, collection of follicular fluid, granulosa cell recovery and quantitation, isolation of theca interna as well as recovery and subsequent classification of oocytes (at $\times 40$ magnification) have all been described in detail elsewhere (McNatty et al., 1983, 1984a). Some oocytes were also fixed in a sodium cacodylate buffer containing $3 \%$ glutaraldehyde $(0.1 \mathrm{M}, \mathrm{pH} 7 \cdot 35)$ for a more detailed histological analysis. After $1 \mathrm{~h}$ in fixative, the oocytes were rinsed twice in $0 \cdot 1 \mathrm{M}$-sodium cacodylate buffer containing $1 \%(\mathrm{w} / \mathrm{v})$ osmium tetroxide. After further rinsing in cacodylate buffer, the 
oocytes were then stained with $2 \cdot 0 \%(\mathrm{w} / \mathrm{v})$ aqueous uranyl acetate for $40 \mathrm{~min}$, dehydrated through a graded series of alcohols (30, 50, 70, 95 and 100\%) and embedded in Spurr's Epoxy Resin. Light microscope sections were stained with $0.5 \%$ toluidine blue in $0.5 \%$ borax.

Classification of atresia in antral follicles. Current methodologies for classifying follicles into various stages of atresia before undertaking biochemical studies (Moor, Hay, Dott \& Cran, 1978; Kruip \& Dieleman, 1982; McNatty, 1982) were, in our hands, too unreliable for identifying those with a functionally active aromatase system in the granulosa cells and/or an LH-responsive theca interna (in terms of androstenedione synthesis). Accordingly, we developed a revised classification system which incorporated some of the criteria identified in the earlier studies. To assess the state of atresia of the various follicles, the following factors were considered: the presence or absence of thecal blood capillaries when the intact (but cleanly dissected) follicles were observed at $\times 10$ magnification; the presence or absence of debris in follicular fluid; the presence and status of the oocyte (healthy, degenerate or absent); the total number of granulosa cells expressed as a percentage of the maximum number of cells observed in a follicle of that size (McNatty et al., 1984a); and the colour (or appearance) of the theca interna (red, pink or white). When these variables were collectively subjected to hierarchical cluster analysis (Genstat, 1981), they separated into four groups termed Grades 1, 2a, $2 \mathrm{~b}$ and 3, with a similarity coefficient within clusters of $0 \cdot 85$. Grade 1 contained follicles with: a vascularized theca interna which was red, pink, or white, no debris in follicular fluid, $>75 \%$ of the maximum number of granulosa cells for a given follicle size and a healthy-looking oocyte. Grade 2 a contained follicles with: a vascularized red to pink theca interna, debris in the follicular fluid, $<75 \%$ of the maximum number of granulosa cells for a given follicle size, and a healthy or degenerate looking oocyte or no oocyte. Grade $2 \mathrm{~b}$ contained follicles with: an avascular white theca interna, no debris in the follicular fluid, $<75 \%$ of the maximum number of granulosa cells for a given follicle size, and a healthy or degenerate oocyte or no oocyte. Grade 3 contained follicles with a white avascular theca interna, debris in the follicular fluid, $<50 \%$ of the maximum number of granulosa cells for a given follicle size, and a healthy or degenerate looking oocyte or no oocyte. Grade 1, which was considered to contain the healthiest follicles, was arbitrarily divided into two subgroups ( $1 \mathrm{a}$ and $1 \mathrm{~b}$ ). All other characteristics being similar Grade 1a follicles were those with a vascularized theca interna which was red to pink and Grade $1 \mathrm{~b}$ follicles had a vascularized theca interna which was white. Based on these 5 subgroups it was presumed that follicles would degenerate along two possible pathways namely: $1 \mathrm{a} \rightarrow 1 \mathrm{~b} \rightarrow 2 \mathrm{~b} \rightarrow 3$ or $1 \mathrm{a} \rightarrow 2 \mathrm{a} \rightarrow 3$.

Classification of follicles based on size and dominance. For each cow, follicles were classified as dominant, large ( $\geqslant 8 \mathrm{~mm}$ diam.), intermediate (5-7.5 mm diam.) or small (2-4.5 mm diam.). With the exception of Day +1 , the dominant follicle was, for each cow, the Grade la follicle with the highest concentration of oestradiol in the follicular fluid and having granulosa cells with the highest aromatase activity. In $30 / 33$ cows, one follicle in each animal was clearly identifiable as the dominant follicle. In the 3 remaining cows the above criteria fitted 2 follicles in each animal; in each of these animals both follicles were classified as dominant.

Dating the oestrous cycle. For each cow, the day of ovariectomy relative to the next presumed day of oestrus was calculated from a knowledge of the previous mean oestrous cycle length and the last date of oestrus. Subsequently, this was confirmed or modified by the histology of the corpus luteum (CL), the weight of $\mathrm{CL}$, the binding characteristics of ${ }^{125} \mathrm{I}$-labelled human chorionic gonadotrophin (hCG) to homogenized luteal tissue, the progesterone secretory characteristics of the dispersed luteal cells over $3 \mathrm{~h}$ in vitro and, in some instances, the $\mathrm{LH}$ and progesterone concentrations in peripheral plasma.

The histological assessment of CL age was especially useful in dating the oestrous cycle on Days -3 to -1 . The histological criteria were as follows: on Days -4 or -5 the luteal cells had granular cytoplasm and were of approximately equal size with large nuclei and well distributed chromatin. 
The arterioles had large lumina. The general picture was of little connective tissue and a uniform appearance. On Day -3 occasional shrunken, darkly staining cells with pycnotic nuclei were scattered unevenly throughout the tissue. A few of the luteal cells were vacuolated. The lumina of the arterioles were smaller than on Day -4 or -5 . In some places, the small arterioles were sclerotic. On Day -2 increasing numbers of shrunken cells with or without pycnotic nuclei were present and there was more variation in the size of the luteal cells. The granules in the luteal cell cytoplasm were less extensive and vacuolation was more pronounced. The arterioles were similar to those on Day -3 but a greater proportion had small lumina. More very small arterioles were evident than before, presumably because of an increase in the thickness of their walls. There was a general increase in the quantity of connective tissue which gave a marbled appearance throughout the CL. There were a few inflammatory cells and cell fragments. On Day -1 the number of shrunken cells was less than on Day -2 . However, there was more variation in the size of the luteal cells which, overall, were smaller relative to those on Day -2 . There was also a reduction in luteal cell number and more connective tissue was evident between the remaining cells. The arterioles had very small lumina and were numerous. There were small but scattered groups of inflammatory cells and debris. On Day 0, the extent of degeneration was much more obvious than on Day -1 and by Day +1 no luteal cells were apparent and most arterioles were sclerotic.

The mean \pm s.e.m. weight of the CL differed little between Days -5 and $-1(4 \cdot 77 \pm 0 \cdot 14 \mathrm{~g}, n$ $=22$ ). On Days 0 and +1 the mean \pm s.e.m. CL weight was $3.49 \pm 0.25 \mathrm{~g}(n=7)$ and $1.62 \pm 0.2 \mathrm{~g}$ $(n=4)$, respectively.

From the criteria outlined by Henderson, Kieboom, McNatty, Lun \& Heath (1984), the calculated equilibrium dissociation constants $(K \mathrm{~d})$ and maximum binding capacities $\left(\mathrm{B}_{\max }\right)$ for specific binding of ${ }^{125}$ I-labelled hCG to homogenized luteal tissue did not differ for $\mathrm{CL}$ recovered from Day -5 to -1 ; over this period the respective mean \pm s.e.m. for $\mathrm{B}_{\max }$ and $K \mathrm{~d}$ was $38.3 \pm 3$ $\mathrm{fm} / \mathrm{mg}$ protein and $0.324 \pm 0.027 \mathrm{nM}(n=11)$. On Day 0 these values were $16.9 \pm 5.7 \mathrm{fm} / \mathrm{mg}$ protein and $0.239 \pm 0.059 \mathrm{nM}(n=4)$ and on Day 1,0 and $0(n=2)$.

Using the method of Henderson \& Moon (1979) to isolate bovine luteal cells, it was found that the luteal progesterone output over $3 \mathrm{~h}$ in response to stimulation by $\mathrm{LH}(\mathrm{NIH}-\mathrm{LH}-\mathrm{B} 10 ; 100 \mathrm{ng} / \mathrm{ml})$ varied with the day of the cycle. From Days -5 to -2 the mean output was relatively constant, i.e. $159 \pm 24 \mathrm{ng} / 10^{6}$ cells $/ 3 \mathrm{~h}(n=6)$, but from cells recovered on Days -1 and 0 the respective outputs were $30 \pm 10(n=4)$ and $19 \pm 9(n=3) \mathrm{ng} / 10^{6}$ cells $/ 3 \mathrm{~h}$.

The mean \pm s.e.m. concentrations $(\mathrm{ng} / \mathrm{ml})$ of $\mathrm{LH}$ in plasma were $1.6 \pm 0.06(n=19)$ on Day $-5,1.5 \pm 0.07(23)$ on Day $-4,1.6 \pm 0.08(20)$ on Day $-3,1.4 \pm 0.1(15)$ on Day $-2,1.7 \pm 0.2$ (10) on Day $-1,17 \pm 6(7)$ on Day -0 and $2 \cdot 6 \pm 0 \cdot 4$ (3) on Day +1 . Since only one blood sample was recovered for $\mathrm{L} \overrightarrow{\mathrm{H}}$ analysis it was not possible to determine whether the ovaries on Day 0 were recovered during the ascending or descending limb of the preovulatory $\mathrm{LH}$ surge.

The mean \pm s.e.m. progesterone concentrations $(\mathrm{ng} / \mathrm{ml})$ in plasma were $5 \cdot 1 \pm 0 \cdot 3(n=19)$ on Day $-5,4 \cdot 6 \pm 0 \cdot 3(23)$ on Day $-4,3 \cdot 8 \pm 0 \cdot 3(20)$ on Day $-3,2 \cdot 6 \pm 0 \cdot 4$ (15) on Day $-2,1 \cdot 3 \pm 0 \cdot 3$ (10) on Day $-1,0.9 \pm 0.2(7)$ on Day 0 and $0.3 \pm 0.1$ (3) on Day +1 .

By assessment of all of the above criteria 30 of the 33 cows were judged to be at the day of oestrous cycle that would have been expected from the previous history, one at Day 0 instead of Day +1 , one at Day 0 instead of -1 and one at Day -2 instead of Day 0 . Overall, 2 cows were judged to be at Day -5 of the cycle, 3 at Day -4, 5 at Day -3, 5 at Day $-2,7$ at Day $-1,7$ at Day 0, and 4 at Day +1 .

The granulosa cell aromatase assays. Granulosa cells from all individual follicles were collected into fresh Medium A. In most instances aromatase assays were performed on individual healthy (Grade 1a) follicles. On some occasions with small healthy follicles ( $<5 \mathrm{~mm}$ diam.) and on many occasions with atretic (Grades $1 \mathrm{~b}, 2 \mathrm{~b}$ and 3 ) follicles too few cells were available for individual assays and so several follicles were pooled. Care was taken to ensure that pools of cells originated from follicles of comparable diameter and stage of atresia. The cells were washed and resuspended 
in Medium A containing sodium bicarbonate $(0.85 \mathrm{~g} / 1)$ so that the final cell concentration was $100-$ $600 \times 10^{3}$ granulosa cells $/ \mathrm{ml} ; 0.5 \mathrm{ml}$ aliquants of these cell suspensions were placed in $10 \times 75 \mathrm{~mm}$ test tubes containing $0.5 \mathrm{ml}$ of a solution of testosterone or androstenedione (for amounts added see below) in Medium A with sodium bicarbonate $(0.85 \mathrm{~g} / \mathrm{l})$, gassed with $5 \% \mathrm{CO}_{2}$ in air, stoppered, and then incubated for $0,0 \cdot 5,1,2,3,4$ or $6 \mathrm{~h}$ in a shaking water bath at $37^{\circ} \mathrm{C}$. All assays were performed in duplicate. At the end of the incubation, the assay tubes were snap frozen to $-70^{\circ} \mathrm{C}$. Subsequently, the tubes were thawed, centrifuged and the supernatants assayed for oestradiol.

Three types of aromatase assays were performed. In one experiment the cells were incubated with androstenedione or testosterone at doses of $0,3,30,300,3000,30000$ or $300000 \mathrm{ng} / \mathrm{ml}$ to compare their respective potencies as substrates. In a second experiment cells from 40 individual healthy follicles $(2.5-14.5 \mathrm{~mm}$ diam.) were subdivided into appropriate aliquants and incubated with $1000 \mathrm{ng}$ testosterone for variable periods of time (see above) or for a fixed time $(3 \mathrm{~h})$ with variable amounts of testosterone. Preliminary studies revealed that the rate of oestradiol accumulation by granulosa cells exposed to different amounts of testosterone or androstenedione could be fitted to the Lineweaver-Burk or Eadie-Hofstee forms of the Michaelis-Menten equation with a correlation coefficient of $>0.9(P<0.01)$. Consequently, the characteristics of aromatase enzyme activity in entire bovine cells were analysed using the enzyme kinetic programme of Crabbe (1982). In the third and most common experiment, the cells (from follicle pools or individual follicles) were incubated in testosterone at a final concentration of $1000 \mathrm{ng} / \mathrm{ml}$ for $3 \mathrm{~h}$. Preliminary studies with $1000 \mathrm{ng}$ testosterone substrate revealed that the rate of oestradiol formation was linear for the first $3 \mathrm{~h}$ for granulosa cells from atretic follicles and for most healthy follicles. However, in some healthy follicles, the rate of metabolism was not always linear after $2 \mathrm{~h}$ and for these follicles the results underestimated the true activity by up to $25 \%$.

Theca interna perifusions. To determine the ability of theca interna to secrete androstenedione in the presence or absence of $\mathrm{LH}$, samples of theca interna were perifused in vitro as described previously (McNatty et al., 1984a). Briefly $25-50 \mathrm{mg}$ theca interna tissue were recovered from the internal face of the follicle wall by microdissection, split into 4 fractions with 2 of these being placed into glass columns $(4 \times 0.7 \mathrm{~cm}$, Econo-column: Bio-Rad Laboratories, CA, U.S.A.) containing 50 mg Sephadex G-25, pre-washed for $1 \mathrm{~h}$ with a perifusion medium consisting of sterile KrebsRinger-bicarbonate buffer containing $1 \% \mathrm{BSA}(\mathrm{w} / \mathrm{v})$ which was gassed continuously with $50 \% \mathrm{O}_{2}$, $45 \% \mathrm{~N}_{2}$ and $5 \% \mathrm{CO}_{2}$. The 3rd thecal fraction was homogenized in $1 \mathrm{ml}$ ethanol to determine the endogenous steroid content and the 4 th was fixed for histological examination to test the purity of the tissue before perifusion. The thecal tissue on the columns was perifused at $37^{\circ} \mathrm{C}$ for $3 \mathrm{~h}$ at a flowrate of $1.4 \mathrm{ml} / \mathrm{min}$ with $12 \mathrm{~min}$ fractions being collected. For 1 of the 2 theca fractions on the columns LH ( $200 \mathrm{ng} / \mathrm{ml}$; NIAMDD-bLH-4) was added to the perifusion medium for $20 \mathrm{~min}$ after the theca had been perifused for $1 \mathrm{~h}$. The other perifused theca was not exposed to $\mathrm{LH}$ and served as an unstimulated control. At the end of the 3 -h period, the tissues were fixed for histological examination and the medium from each tube frozen until assayed for androstenedione by a specific radioimmunoassay (RIA) (McNatty, Gibb, Dobson, Thurley \& Findlay, 1981). The androstenedione output from theca was expressed as the cumulative output (ng) per $10 \mathrm{mg}$ theca interna over the 3-h period during and after $\mathrm{LH}$ stimulation or after control media perifusion. Analysis of all thecae fixed for histological examination revealed that $70-100 \%$ of the cell population was theca interna: the major contaminants were theca externa, stroma and/or red blood cells and only a few granulosa cells (i.e. $<5$ per $7 \mu \mathrm{m}$ section) were ever present.

Hormone assays. All steroids were measured using previously published RIA procedures (McNatty et al., 1981, 1982). Androstenedione, testosterone and oestradiol were extracted from peripheral blood $(10 \mathrm{ml})$ or ovarian venous blood $(1 \mathrm{ml})$ with diethyl ether $(2 \times 5 \mathrm{vol})$ and then separated by the Lipidex 5000, or Sephadex LH-20 column chromatographic methods outlined elsewhere (McNatty et al., 1981). Progesterone in peripheral plasma (1 ml) was measured using an RIA procedure (Thorneycroft \& Stone, 1972). In follicular fluid progesterone, androstenedione and 
oestradiol were measured directly in diluted (10-100-fold with $0 \cdot 1 \mathrm{M}$-phosphate-buffered saline, PBS, pH 7.2) aliquants of follicular fluid. Testosterone was measured in follicular fluid after it had been diluted (10-100-fold) with PBS and extracted twice with 5 volumes of diethyl ether.

Androstenedione in Krebs-Ringer solution (from the thecal columns) and oestradiol in the aromatase assay solutions were measured directly without extraction.

Details regarding the working dilutions and specifications of the progesterone (WA-26), androstenedione (WA-965), testosterone (WA-36) and oestradiol (WA-27) antisera are provided elsewhere (McNatty et al., 1981, 1984b).

The detection limit of steroids in follicular fluid was $2 \mathrm{ng} / \mathrm{ml}$. The detection limits of progesterone, androstenedione, testosterone and oestradiol in plasma were $200,2,1$ and $1 \mathrm{pg} / \mathrm{ml}$ respectively. The intra- and inter-assay coefficients of variation for all the above steroid assays were $<12 \%$.

Statistical procedures. The criteria used to investigate the various stages of follicular atresia were subjected to cluster analysis using the single-linkage procedure outlined in Genstat (1981). With this method, the similarity coefficient between two clusters is the greatest between any two units, one in each cluster. All units start in separate clusters and the algorithm clusters those with similarity levels greater than some preset level (between 0 and 1).

When analysing the data on hormones in follicular fluid or plasma, they were first normalized by $\log$ transformation and then subjected to analysis of variance (ANOVA) followed by pair-wise comparisons of means using the error mean square of the ANOVA. The results from these studies were expressed as geometric means and $95 \%$ confidence limits.

\section{Results}

Hormones in peripheral and ovarian venous plasma

The concentrations (geometric means and $95 \%$ confidence limits) of androstenedione, testosterone and oestradiol in peripheral plasma and in the veins draining the ovary containing a dominant follicle or the contralateral ovary on different days of the oestrous cycle are summarized in Table 1. In general, the mean concentrations of steroids in ovarian venous blood exceeded those in peripheral plasma, but the range of values in the former was large and significant differences for all steroids were only observed on Day 0 . With the exception of Day -3 , the oestradiol concentrations in veins draining ovaries with a dominant follicle were always significantly greater than those in peripheral plasma $(P<0.05)$. With the exception of Day -1 , the androstenedione concentrations in the veins draining contralateral ovaries were always significantly greater than in peripheral plasma $(P<0.05)$. Oestradiol concentrations from the dominant ovary were significantly greater than those from the contralateral ovary $(P<0.05)$ only on Day 0 .

\section{Ovarian weights and follicle numbers}

The weights of ovaries with and without CL (means \pm s.e.m.) were $10.07 \pm 0.44 \mathrm{~g}(n=31)$ and $5.71 \pm 0.25 \mathrm{~g}(33)$ respectively. The mean \pm s.e.m. number of follicles $\geqslant 2 \mathrm{~mm}$ diameter per cow was $52.4 \pm 4 \cdot 1(n=33$ cows). The mean \pm s.e.m. number of follicles in ovaries with and without CL were $26 \cdot 5 \pm 2 \cdot 3(31)$ and $25 \cdot 5 \pm 2 \cdot 2$ (33) respectively.

\section{Follicular health and atresia}

The distribution of healthy ovarian follicles (Grade la) with respect to diameter and day of the oestrous cycle is shown in Text-fig. 1 . On each day, there was at least 1 large ( $\geqslant 8 \mathrm{~mm}$ diam.) healthy follicle in each cow. On Days $-5,-4,-3,-2,-1,0$ and +1 , the chance that the largest follicle in the ovary was the dominant follicle was $50(1 / 2$ cows), $66 \cdot 7(2 / 3), 60 \cdot 0(3 / 5), 80(4 / 5), 85 \cdot 7(6 / 7), 71 \cdot 4$ 
Table 1. Steroid concentrations in peripheral plasma, and in ovarian veins draining ovaries with a dominant follicle and from the contralateral ovaries

\begin{tabular}{|c|c|c|c|c|c|}
\hline \multirow[b]{2}{*}{ Plasma source } & \multirow{2}{*}{$\begin{array}{l}\text { Day from } \\
\text { oestrus }\end{array}$} & \multirow{2}{*}{$\begin{array}{l}\text { No. of } \\
\text { cows }\end{array}$} & \multicolumn{3}{|c|}{ Plasma steroid concentrations $(\mathrm{pg} / \mathrm{ml})$} \\
\hline & & & Androstenedione & Testosterone & Oestradiol \\
\hline Peripheral & & & $\begin{array}{r}7^{a, p} \\
(2-29)\end{array}$ & $\begin{array}{c}14^{p} \\
(5-40)\end{array}$ & $\begin{array}{c}15^{a} \\
(5-43)\end{array}$ \\
\hline Ovary with dominant follicle* & -3 & 5 & $\begin{array}{c}37^{a} \\
(3-459)\end{array}$ & $\begin{array}{c}27^{\mathrm{p}} \\
(18-42)\end{array}$ & $\begin{array}{c}98^{\mathrm{a}} \\
(4-1939)\end{array}$ \\
\hline Contralateral ovary & & & $\begin{array}{c}464^{\mathrm{b}, q} \\
(45-4722)\end{array}$ & $\begin{array}{c}142^{q} \\
(37-556)\end{array}$ & $\begin{array}{c}30^{\mathrm{a}} \\
(11-78)\end{array}$ \\
\hline Peripheral & & & $\begin{array}{r}20^{\mathrm{a}, \mathrm{p}} \\
(5-74)\end{array}$ & $\begin{array}{c}23^{a} \\
(4-132)\end{array}$ & $\begin{array}{c}19^{a} \\
(6-62)\end{array}$ \\
\hline Ovary with dominant follicle* & -2 & 5 & $\begin{array}{c}493^{\mathrm{b}, \mathrm{q}} \\
(90-2724)\end{array}$ & $\begin{array}{c}104^{\mathrm{a}} \\
(36-299)\end{array}$ & $\begin{array}{c}144^{\mathrm{b}} \\
(20-706)\end{array}$ \\
\hline Contralateral ovary & & & $\begin{array}{c}178^{\mathrm{b}} \\
(45-2018)\end{array}$ & $\begin{array}{c}110^{\mathrm{a}} \\
(27-441)\end{array}$ & $\begin{array}{c}38^{\mathrm{a}} \\
(15-95)\end{array}$ \\
\hline Peripheral & & & $\begin{array}{c}11^{\mathrm{a}} \\
(2-144)\end{array}$ & $\begin{array}{c}14^{\mathrm{a}} \\
(2-171)\end{array}$ & $\begin{array}{c}18^{\mathrm{a}} \\
(16-21)\end{array}$ \\
\hline Ovary with dominant follicle* & -1 & 3 & $\begin{array}{l}185^{a} \\
(5-7044)\end{array}$ & $\begin{array}{c}86^{a} \\
(23-314)\end{array}$ & $\begin{array}{c}164^{b} \\
(19-1380)\end{array}$ \\
\hline Contralateral ovary & & & $\begin{array}{l}118^{a} \\
(4-3790)\end{array}$ & $\begin{array}{c}61^{a} \\
(6-614)\end{array}$ & $\begin{array}{l}106^{\mathrm{b}} \\
(8-1352)\end{array}$ \\
\hline Peripheral & & & $\begin{array}{r}10^{\mathrm{a}, \mathrm{p}} \\
(4-27)\end{array}$ & $\begin{array}{c}7^{\mathrm{a}} \\
(2-23)\end{array}$ & $\begin{array}{r}14^{\mathrm{a}, \mathrm{p}} \\
(7-31)\end{array}$ \\
\hline Ovary with dominant follicle* & 0 & 5 & $\begin{array}{c}191^{\text {b.q }} \\
(31-1164)\end{array}$ & $\begin{array}{c}94^{\mathrm{b}} \\
(34-284)\end{array}$ & $\begin{array}{c}1326^{\text {b.q }} \\
(270-6568)\end{array}$ \\
\hline Contralateral ovary & & & $\begin{array}{c}86^{\mathrm{c}, \mathrm{q}} \\
(38-240)\end{array}$ & $\begin{array}{c}60^{\mathrm{b}} \\
(17-209)\end{array}$ & $\begin{array}{c}162^{\mathrm{b}, \mathrm{q}} \\
(46-1635)\end{array}$ \\
\hline
\end{tabular}

Values are geometric means with $95 \%$ confidence limits in parentheses.

Numbers in columns for each day from oestrus with a different alphabetical superscript are significantly different from one another: ${ }^{\text {a.b.c }} P<0.05 ; \mathrm{p}, q$ P $<0.01$ (analysis of variance).

* Dominant refers to the Grade la (healthy) follicles in each cow with the highest concentration of oestradiol in follicular fluid and with granulosa cells having the highest level of extant aromatase activity.

$(5 / 7)$ and $100 \%(4 / 4)$. The mean \pm s.e.m. number of healthy follicles ( $\geqslant 2 \mathrm{~mm}$ diam.) per cow was $7.6 \pm 1.0 ;$ this represented $14.9 \pm 1.6 \%$ of the follicle population.

Most (i.e. $85 \cdot 1 \pm 1 \cdot 5 \%$ ) antral follicles ( $\geqslant 2 \mathrm{~mm}$ diam.) were atretic (i.e. Grades $1 \mathrm{~b}, 2 \mathrm{a}, 2 \mathrm{~b}$ and 3 ). The proportions of large ( $\geqslant 8 \mathrm{~mm}$ diam.), intermediate (5-7.5 mm diam.) or small follicles (2-4.5 $\mathrm{mm}$ diam.) in atresia did not vary with the day of the oestrous cycle. There was, however, an influence of follicular diameter on the distribution of follicles at each stage of atresia. The mean number of large follicles per cow was $2 \cdot 4 \pm 0 \cdot 2$; of this number $30 \pm 6 \%$ per cow were atretic. Nearly all, $16 / 17(94 \cdot 1 \%)$ of these atretic follicles were in Grade $2 a$ atresia; only one $(5 \cdot 9 \%)$ was in Grade $1 \mathrm{~b}$ atresia. The mean number of intermediate-sized follicles per cow was $5 \cdot 3 \pm 0 \cdot 6$; of this number $67.3 \pm 7.4 \%$ were atretic. Overall the distribution of intermediate-sized follicles at Grade $1 \mathrm{~b}, 2 \mathrm{a} ; 2 \mathrm{~b}$ and 3 atresia was $37.0,48.9,5.4$ and $8.7 \%$ respectively. The mean number of small follicles (2-4.5 mm diam.) per cow was $45.9 \pm 4.5$; of this number $92.9 \pm 1.4 \%$ were atretic. Overall, the distribution of small follicles at Grades $1 \mathrm{~b}, 2 \mathrm{a}, 2 \mathrm{~b}$ and 3 atresia was $25 \cdot 6,22 \cdot 7,15 \cdot 0$ and $36.8 \%$.

Of all Grade $2 \mathrm{a}, 2 \mathrm{~b}$ or 3 follicles, $53 \%$ contained oocytes which appeared healthy, $13 \%$ contained oocytes which were clearly degenerate and from $34 \%$ of the follicles no oocyte was recovered. Healthy oocytes were not uncommon even in Grade 3 follicles which were severely deficient in granulosa cells. 
(2)

(3)

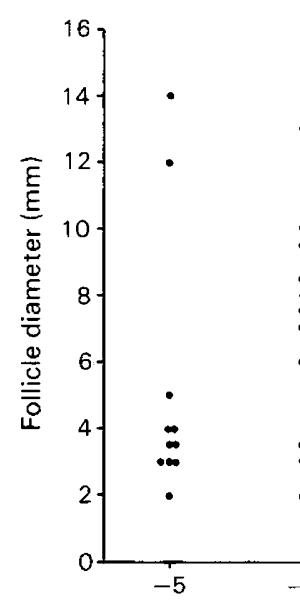

(5)

(5)
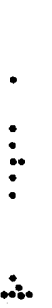

$\therefore \quad \therefore$

:
(7)

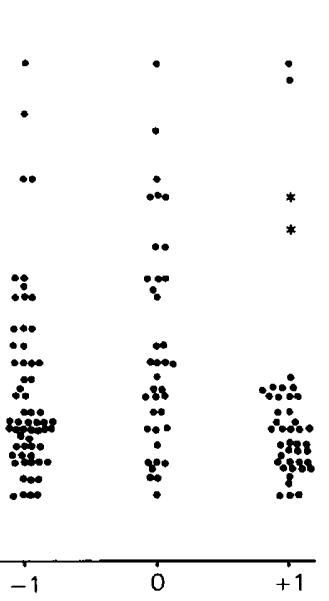

Days from oestrus

Text-fig. 1. Total number of healthy follicles of different size with respect to day from oestrus (Day 0). Numbers in parentheses refer to number of cows stüdied on each day of the cycle.

* Haemorrhagic presumptive preovulatory follicles.

\section{Follicular diameter and cell number}

There was no effect of day of oestrous cycle on the diameter of the largest healthy (Grade 1a) follicle (Text-fig. 1), the diameter of the dominant follicle or their respective numbers of granulosa cells.

\section{Steroids in follicular fluid}

There was no difference for any steroid when the results from anaesthetized animals were compared with those from the slaughterhouse. Consequently, the results from these two groups of animals were pooled when appropriate. The concentrations (geometric means and $95 \%$ confidence limits) of progesterone, androstenedione, testosterone and oestradiol in the fluid of dominant, large, intermediate or small healthy (Grade 1a) follicles regardless of the day of oestrous cycle are shown in Table 2. As healthy follicles increased in size there were significant increases in the concentrations of progesterone and oestradiol $(P<0.05)$ and significant decreases in the concentrations of androstenedione and testosterone $(P<0.01)$. The dominant follicles differed from the large follicles in that they contained significantly higher concentrations of oestradiol $(P<$ 0.01 ). When the data for each size of healthy follicle were analysed with respect to the day of the oestrous cycle, no significant changes in the concentration of progesterone, androstenedione or testosterone were observed. The only exception to this was noted for progesterone concentrations in dominant follicles on Day +1 . On this day the progesterone concentrations in two follicles were 485 and $775 \mathrm{ng} / \mathrm{ml}$; these concentrations were at least 16 -fold greater than in all other dominant follicles on all other days of the cycle. There were no significant changes in oestradiol concentrations for small or intermediate-sized follicles with respect to day of cycle. For the large healthy follicles or dominant follicles, however (see Table 3), the mean concentrations of oestradiol on Day 0 were 210 -fold higher than those on other days of the cycle although high oestradiol concentrations were also present in some follicles on Days $-5,-4,-3,-2$ and -1 , but not on Day +1 .

The concentrations (geometric means and $95 \%$ confidence limits) of progesterone, androstenedione, testosterone and oestradiol in the fluid of all atretic follicles (Grades $1 \mathrm{~b}$ to 3 ) with respect to follicle diameter are summarized in Table 2. The data refer to follicles at Grades $1 \mathrm{~b}, 2 \mathrm{a}, 2 \mathrm{~b}$ or 3 of 
Table 2. Steroid concentrations (geometric means and $95 \%$ confidence limits) in healthy and atretic bovine follicles

\begin{tabular}{|c|c|c|c|c|c|}
\hline \multirow{2}{*}{$\begin{array}{l}\text { Follicle type } \\
\text { or diameter } \\
(\mathrm{mm})\end{array}$} & \multirow{2}{*}{$\begin{array}{l}\text { No. of } \\
\text { follicles }\end{array}$} & \multicolumn{4}{|c|}{ Steroid $(\mathrm{ng} / \mathrm{ml})$} \\
\hline & & Progesterone & Androstenedione & Testosterone & Oestradiol \\
\hline \multicolumn{6}{|l|}{ Healthy } \\
\hline Dominant* & 32 & $\begin{array}{c}30^{\mathrm{a}, \mathrm{p}} \\
(24-39)\end{array}$ & $\begin{array}{l}11^{\text {a.p }} \\
(9-15)\end{array}$ & $\begin{array}{c}17^{\mathrm{a}, \mathrm{p}} \\
(11-27)\end{array}$ & $\begin{array}{c}60^{\mathrm{a}, \mathrm{p}} \\
(35-105)\end{array}$ \\
\hline$\geqslant 8$ & 56 & $27^{\mathrm{a}, \mathrm{p}}$ & $10^{\mathrm{a}, \mathrm{p}}$ & $14^{\mathrm{a}, \mathrm{p}}$ & $27^{\mathrm{b}, \mathrm{q}}$ \\
\hline & & $(22-33)$ & $(8-12)$ & $(10-19)$ & $(17-42)$ \\
\hline $5-7 \cdot 5$ & 45 & $20^{\mathrm{b}, \mathrm{q}}$ & $20^{\mathrm{b}, \mathrm{p}}$ & $31^{\mathrm{b}, \mathrm{q}}$ & $7^{\mathrm{c}, \mathrm{r}}$ \\
\hline & & $(16-23)$ & $(15-25)$ & $(23-42)$ & $(5-9)$ \\
\hline $2-4 \cdot 5$ & 77 & $\begin{array}{c}15^{\mathrm{c}, \mathrm{q}} \\
(13-18)\end{array}$ & $\begin{array}{c}34^{\mathrm{c}, q} \\
(27-43)\end{array}$ & $\begin{array}{c}59^{\mathrm{c}, \mathrm{r}} \\
(47-74\}\end{array}$ & $\begin{array}{r}4^{\mathrm{d}, \mathrm{r}} \\
(3-4)\end{array}$ \\
\hline \multicolumn{6}{|l|}{ Atretic } \\
\hline$\geqslant 8$ & 17 & $\begin{array}{c}176^{\mathrm{a}, \mathrm{p}} \\
(100-305)\end{array}$ & $\begin{array}{c}9^{\mathrm{a}, \mathrm{p}} \\
(5-15)\end{array}$ & $\begin{array}{l}15^{\mathrm{a}, \mathrm{p}} \\
(6-38)\end{array}$ & $\begin{array}{c}2^{\mathrm{a}} \\
(2-2)\end{array}$ \\
\hline $5-7.5$ & 73 & $\begin{array}{c}33^{\mathrm{b}, \mathrm{q}} \\
(25-45)\end{array}$ & $\begin{array}{c}17^{\mathrm{b}, \mathrm{p}} \\
(14-21)\end{array}$ & $\begin{array}{c}23^{\mathrm{a}, \mathrm{p}} \\
(18-30)\end{array}$ & $\begin{array}{c}3^{a} \\
(2-3)\end{array}$ \\
\hline $2-4 \cdot 5$ & 707 & $\begin{array}{c}30^{\mathrm{b}, \mathrm{q}} \\
(28-33)\end{array}$ & $\begin{array}{c}35^{\mathrm{c}, \mathrm{q}} \\
(32-37)\end{array}$ & $\begin{array}{c}42^{\mathrm{b}, \mathrm{q}} \\
(38-46)\end{array}$ & $\begin{array}{c}3^{\mathrm{a}} \\
(2-3)\end{array}$ \\
\hline
\end{tabular}

Numbers (in columns) for either healthy or atretic follicles with a different alphabetical superscript are significantly different from one another: ${ }^{\mathrm{a}, \mathrm{b}, \mathrm{c}, \mathrm{d}} \boldsymbol{P}<0.05 ; \mathrm{p}, \mathrm{q}, \mathrm{r} P<0.01$ (analysis of variance).

* A dominant follicle was the Grade la follicle in each cow with the highest concentration of oestradiol in follicular fluid, and with the granulosa cells having the highest level of extant aromatase activity.

Table 3. Oestradiol concentrations $(\mathrm{ng} / \mathrm{ml})$ in dominant* or large healthy ( $\geqslant 8 \mathrm{~mm}$ diam.) follicles during the bovine oestrous cycle

\begin{tabular}{|c|c|c|c|c|c|c|}
\hline \multirow{2}{*}{$\begin{array}{l}\text { Follicle } \\
\text { type or } \\
\text { diameter }\end{array}$} & \multicolumn{6}{|c|}{ Days from oestrus (Day $0=$ oestrus) } \\
\hline & -5 and -4 & -3 & -2 & -1 & 0 & +1 \\
\hline \multicolumn{7}{|l|}{ Dominant } \\
\hline Oestradiol conc. & $\begin{array}{c}44^{\mathrm{a}} \\
(13-141)\end{array}$ & $\begin{array}{c}30^{\mathrm{a}} \\
(3-324)\end{array}$ & $\begin{array}{c}21^{a} \\
(4-129)\end{array}$ & $\begin{array}{c}83^{\mathrm{a}, \mathrm{b}} \\
(37-185)\end{array}$ & $\begin{array}{c}256^{\mathrm{b}} \\
(87-750)\end{array}$ & 20 \\
\hline No. of follicles & 5 & 5 & 5 & 8 & 7 & 2 \\
\hline \multicolumn{7}{|l|}{$\geqslant 8 \mathrm{~mm}$} \\
\hline Oestradiol conc. & $\begin{array}{c}10^{\mathrm{a}} \\
(3-32)\end{array}$ & $\begin{array}{c}16^{a} \\
(5-60)\end{array}$ & $\begin{array}{c}15^{\mathrm{a}} \\
(7-32)\end{array}$ & $\begin{array}{c}57^{\mathrm{a}, \mathrm{b}} \\
(27-123)\end{array}$ & $\begin{array}{c}104^{\mathrm{b}} \\
(24-455)\end{array}$ & 20 \\
\hline No. of follicles & 8 & 9 & 16 & 11 & 10 & 2 \\
\hline
\end{tabular}

Values are geometric means with $95 \%$ confidence limits in parentheses.

Numbers (in rows) with a different alphabetical superscript are significantly different from one another, $P<0.05$ (analysis of variance).

* A dominant follicle was the Grade la follicle in each cow with the highest concentration of oestradiol in follicular fluid and with granulosa cells having the highest level of extant aromatase activity.

atresia since no differences in steroid concentrations between these different grades of atresia were observed. Compared to small or intermediate sized atretic follicles, large atretic follicles contained the highest concentrations of progesterone, the lowest concentrations of androstenedione and testosterone and uniformly low or undetectable concentrations of oestradiol. 
When the data for each size of atretic follicles were analysed with respect to day of the oestrous cycle, no significant changes were noted. Of the 17 large atretic follicles, 16 were assessed at Grade $2 \mathrm{a}$ atresia. When the steroid concentrations in these predominantly Grade $2 \mathrm{a}$ atretic follicles were compared to those in healthy or dominant follicles of comparable size, the atretic follicles contained the highest progesterone $(P<0.01)$ and the lowest oestradiol concentrations $(P<0.01)$ whereas the concentrations of androstenedione and testosterone were similar (see Table 2). Moreover, in small and intermediate atretic follicles the progesterone concentrations were significantly greater (both $P<0.01$ ) than those in the respective healthy follicles (Table 2).

\section{Aromatase activity in granulosa cells}

The respective abilities of testosterone and androstenedione to be utilized by bovine granulosa cells for the synthesis of oestradiol are shown in Text-fig. 2 . These androgens were equipotent as substrates for oestrogen biosynthesis.

The levels of aromatase activity in granulosa cells from healthy (Grade 1a), small (2-4.5 mm diam.), intermediate (5-7.5 mm diam.), large ( $\geqslant 8 \mathrm{~mm}$ diam.) and dominant follicles were $2.8 \pm 0.4$ (23 follicles), $12.5 \pm 1 \cdot 3(33), 65.0 \pm 11.2(36)$ and $92.5 \pm 15.6(23) \mathrm{ng} / 10^{6}$ cells $/ 3 \mathrm{~h}$ respectively (intermediate versus small, $P<0.01$; large versus intermediate, $P<0.01$; dominant versus large, $P>0.05$ ). Granulosa cells from all atretic follicles, regardless of grade of atresia or follicle size, contained little or no discernible aromatase activity $\left(<2 \mathrm{ng} / 10^{6}\right.$ cells $/ 3 \mathrm{~h}, 195$ follicles tested).

Aromatase activity in the granulosa cells was influenced by substrate concentration and incubation time. The characteristics of aromatase enzyme activity in cells from dominant follicles during the oestrous cycle are summarized in Table 4 . Dominant follicles on Day -4 to -1 sometimes contained granulosa cells with similar aromatase enzyme characteristics to those at oestrus. Overall, the apparent $K_{\mathrm{m}}$ values in healthy but not dominant follicles ( $\geqslant 5 \mathrm{~mm}$ diam.; $n=$ 14) were highly variable (i.e. undetectable or ranged from 40 to $448 \mathrm{nM}$ ) whereas the $V_{\max }$ values which ranged from 0 to $50 \mathrm{ng}$ oestradiol $/ 10^{6}$ cells $/ 3 \mathrm{~h}$ were consistently lower than those in cells from dominant follicles. The $V_{\max }$ and apparent $K_{\mathrm{m}}$ values in cells from a 10 -mm presumptive preovulatory follicle on Day +1 were $0 \mathrm{nM}$ and undetectable respectively. In cells from small healthy follicles (2-4.5 mm diam.) the apparent $K_{\mathrm{m}}$ values on Days -5 to 0 were undetectable or ranged from 621 to $1022 \mathrm{nM}$ ( 9 follicles tested), whereas on Day +1 ( 2 follicles) they ranged from 27 to $37 \mathrm{~nm}$. The $V_{\max }$ values in small healthy follicles on Days -5 to 0 ( 9 follicles) ranged from $0-4$ $\mathrm{ng} / 10^{6}$ cells $/ 3 \mathrm{~h}$, whereas on Day +1 (2 follicles) they ranged from 12 to $26 \mathrm{ng} / 10^{6} \mathrm{cells} / 3 \mathrm{~h}$.

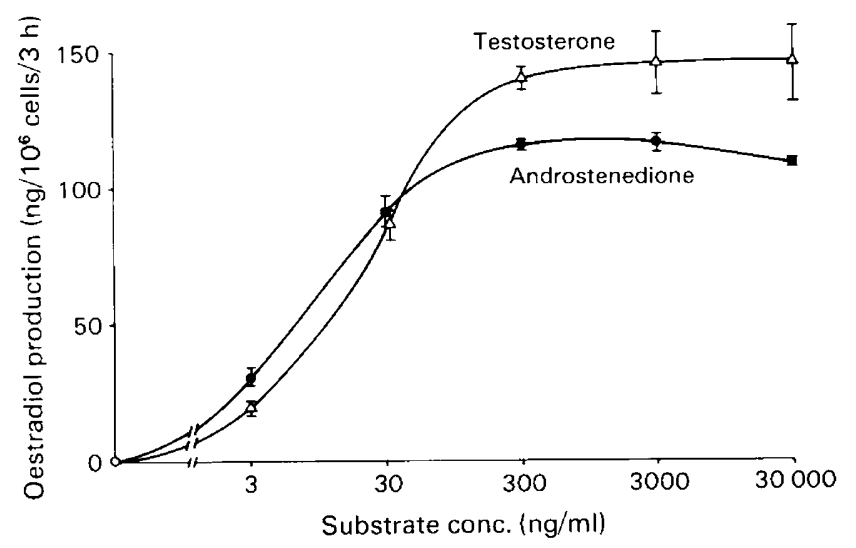

Text-fig. 2. Oestradiol output by bovine granulosa cells $(250000$ cells/tube) from a pool of healthy large $(\geqslant 8 \mathrm{~mm}$ diam.) follicles incubated with different concentrations of testosterone or androstenedione. 
Table 4. Characteristics of aromatase enzyme activity in dispersed bovine granulosa cells from dominant* follicles during the oestrous cycle

\begin{tabular}{lccc}
\hline & \multicolumn{3}{c}{ Days from oestrus (Day 0) } \\
\cline { 2 - 4 } & -4 and -3 & -2 and -1 & 0 \\
\hline$K \mathrm{~m}(\mathrm{nM})$ & 136 & 89 & 144 \\
& $(118-156)$ & $(18-132)$ & $(74-209)$ \\
$V_{\max }$ (ng oestradiol $/ 10^{6}$ cells/3 h) & 56 & 86 & 116 \\
No. of follicles & $(21-296)$ & $(38-120)$ & $(109-244)$ \\
\hline
\end{tabular}

Values are medians with ranges in parentheses.

* Dominant refers to the Grade la (healthy) follicles in each cow with the highest concentration of oestradiol in follicular fluid and with the highest level of extant aromatase activity.

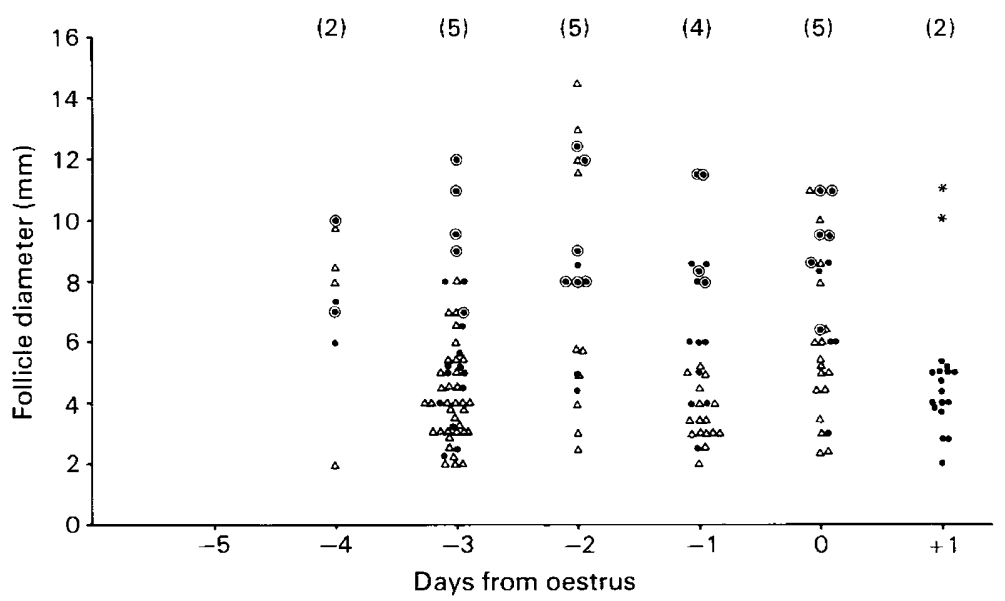

Text-fig. 3. Scatter graph showing the relationship between diameter of healthy follicles and day of oestrous cycle relative to the day of oestrus (Day 0 ). $\odot$, Dominant follicles with aromatase activity; $\rightarrow$ and $\triangle$, healthy but not dominant follicles containing granulosa cells with or without aromatase activity respectively; ${ }^{*}$ haemorrhagic presumptive ovulatory follicles which were devoid of aromatase activity. Aromatase activity was assessed after incubation of granulosa cells with $1000 \mathrm{ng}$ testosterone. The points refer to the total number of healthy ovarian follicles ( $\geqslant 2 \mathrm{~mm}$ diam.) from the number of cows indicated in parentheses.

Aromatase activity was examined in cells from all healthy follicles (using $1000 \mathrm{ng}$ testosterone and a 3-h incubation time) from $23 / 33$ cows with respect to day of the oestrous cycle (Text-fig. 3 ). Follicles with cells producing $>2 \mathrm{ng}$ oestradiol $/ 10^{6}$ cêlls $/ 3 \mathrm{~h}$ were recorded as having activity. On Days -5 to 0 , the number of intermediate and large healthy follicles with aromatase activity was variable $(0-100 \%)$. On Day +1 , the recently ruptured or presumptive preovulatory follicles had no discernible aromatase activity (i.e. $<2 \mathrm{ng}$ oestradiol $/ 10^{6} \mathrm{cells} / 3 \mathrm{~h}$ ) although all the small and intermediate-sized follicles had some activity $\left(\geqslant 2 \mathrm{ng}\right.$ oestradiol $\left./ 10^{6} \mathrm{cells} / 3 \mathrm{~h}\right)$.

\section{$L H$ induced steroidogenesis in theca interna}

Theca interna tissue from small, intermediate or large healthy follicles (Grade 1a, $n=67$ ) responded to $\mathrm{LH}$ and produced $2 \cdot 8-15$-fold more $(P<0 \cdot 01)$ androstenedione than did the 
unstimulated tissues. The only exception to this was for LH-treated theca interna recovered from presumptive preovulatory follicles $(n=2)$ on Day +1 ; these tissues did not respond to LH and produced only trivial amounts of androstenedione (i.e. 3 and $9 \mathrm{ng} / 10 \mathrm{mg} / 3 \mathrm{~h}$ ). For the other follicles that were $2-4.5 \mathrm{~mm}, 5-7.5 \mathrm{~mm}, \geqslant 8 \mathrm{~mm}$ (on Days -5 to +1 ) or dominant (on Days -5 to 0 ), the respective androstenedione outputs by $\mathrm{LH}$-stimulated thecae were $427 \pm 101$ (mean \pm s.e.m.; $n=$ $7), 393 \pm 47(14), 425 \pm 35(23)$ and $453 \pm 36(23) \mathrm{ng} / 10 \mathrm{mg}$ theca/ $3 \mathrm{~h}$ while the respective outputs from the unstimulated controls were $58(2), 86 \pm 13(7), 96 \pm 5$ (19) and $87 \pm 12(15) \mathrm{ng} / 10 \mathrm{mg}$ theca $/ 3 \mathrm{~h}$. These data show that there was no relationship between follicular diameter and thecal androgen output when the results were expressed per $10 \mathrm{mg}$ tissue. It was also evident that the thecal androstenedione output from dominant follicles was similar to that from small, intermediate or large healthy follicles. When the data were analysed with respect to day from oestrus, no significant differences were observed. Even for the dominant follicle on Day 0, the level of LHinduced androstenedione biosynthesis was similar to that on other days of the oestrous cycle.

The LH-stimulated thecae from large atretic (Grade $2 \mathrm{a})$ follicles $(n=9)$ produced significantly less androstenedione than did the controls (LH-treated theca, $27 \pm 6$ androstenedione/10 mg theca $/ 3 \mathrm{~h}$; control theca, $61 \pm 8 \mathrm{ng} / 10 \mathrm{mg} / 3 \mathrm{~h} ; P<0.01$ ). In contrast LH-stimulated theca interna from small and intermediate atretic (Grades $1 \mathrm{~b}$ and $2 \mathrm{a}$ ) follicles $(n=10)$ produced $1 \cdot 2-8$-fold more androstenedione than did their respective controls (LH-treated theca, $310 \pm 32 \mathrm{ng} / 10 \mathrm{mg} / 3 \mathrm{~h}$; controls, $68 \pm 7 \mathrm{ng} / 10 \mathrm{mg} / 3 \mathrm{~h} ; P<0.01$ ). Thecae internae from Grades $2 \mathrm{~b}$ and 3 follicles were not studied because of the difficulties in identifying this tissue at these stages of atresia.

\section{Relationship between LH-induced steroidogenesis in theca interna and extant aromatase activity in granulosa cells}

The relationship between the $\mathrm{LH}$-responsiveness of theca interna with respect to androstenedione production and the level of aromatase activity in granulosa cells from 57 individual healthy follicles ( $\geqslant 5 \mathrm{~mm}$ diam.) was examined. An LH-responsive theca interna was considered to be that producing more than twice the control outputs whereas granulosa cells having aromatase activity were those producing $\geqslant 2 \mathrm{ng}$ oestradiol $/ 10^{6} \mathrm{cells} / 3 \mathrm{~h}$. Most (i.e. $39 / 57$ or $68 \%$ ) of the healthy follicles contained measurable activity in both cell types although $18 / 57(32 \%)$ contained an LH-responsive theca but no granulosa cell activity. No follicles were found with aromatase activity in granulosa cells in the absence of an LH-responsive theca or an absence of steroidogenic activity in both cell types.

\section{Discussion}

The results of the present study confirm and extend the notion that there is at least one large healthy follicle present in the ovaries of the cow on each day from Day -5 until ovulation, and that on each of these days there are 1-3 ovarian follicles $\geqslant 5 \mathrm{~mm}$ in each cow with an LH-responsive theca interna and extant aromatase activity in granulosa cells. The demonstration of highly variable aromatase activity in dominant follicles, highly variable concentrations of oestradiol in ovarian venous blood and follicular fluid and variable numbers of atretic follicles each day from Day -5 to Day 0 is consistent with the possibility that there is a continual turnover of follicles with a potential to ovulate (Matton et al., 1981). Alternatively, and as a consequence of episodic gonadotrophin secretion (Hansel \& Convey, 1983), it is possible that there are variable periodicities of activity and quiescence with respect to oestrogen biosynthesis in healthy follicles ( $\geqslant 5 \mathrm{~mm}$ diam.) which have a relatively slow turnover time (Scaramuzzi et al., 1980).

In small healthy follicles (i.e. $<5 \mathrm{~mm}$ diam.) the presence of high androstenedione and testosterone, and low or undetectable concentrations of oestradiol in follicular fluid (Table 2), low or undetectable extant aromatase activity in the granulosa cells (Text-fig. 4; Table 4) and an LH- 
responsive theca provide strong evidence that early developing antral follicles develop a competence to synthesize androgens before appreciable aromatase activity is expressed in the granulosa cells. Presumably the increasing concentration of oestradiol at the expense of androgen as healthy follicles enlarge beyond $4.5 \mathrm{~mm}$ diameter (Table 2) is a direct consequence of an induction or activation of aromatase activity in granulosa cells.

In large healthy or dominant follicles, the LH responsiveness of theca interna (per unit mass of tissue) was similar to that in intermediate or small healthy follicles and did not differ with the day of the oestrous cycle. In dominant follicles, the level of androgen substrate required for aromatization by granulosa cells at $50 \% V_{\max }$ can be derived from the apparent $K \mathrm{~m}$, value (i.e. 18-296 nM, Table 4). These amounts of androgen can readily be synthesized by LH-stimulated thecal tissues under in-vitro conditions (see 'Results' and McNatty et al., 1984a). Therefore, the level of oestradiol biosynthesis by a dominant follicle in vivo is probably dependent upon the plasma concentration of LH and/or the LH pulse frequency as well as on the mass of theca interna which is known to increase with increasing follicular diameter (McNatty et al., 1984a).

The follicle classification system described herein has provided a framework in which to examine some aspects of atresia. Of the intermediate and large follicles, between 1 and 5 per cow were assessed to be healthy (Grade 1a): 2-4 of these contained low or undetectable extant aromatase activity in their granulosa cells even though the theca from such follicles responded to LH by secreting androstenedione. Early atresia in intermediate or large follicles may be due to a failure to stimulate aromatase activity or to a loss of enzyme activity preceding any degenerative changes in the theca interna. In either case any treatment to enhance twin ovulations in cattle may need to sustain or activate aromatase activity in more than one of the large and/or intermediatesized healthy follicles while these follicles await the preovulatory rise in LH secretion.

Of the small follicle population, $\sim 93 \%$ were assessed to be atretic leaving on average only 3 healthy follicles per cow per day of cycle. Although the mean level of aromatase activity in small healthy follicles was indistinguishable from that in atretic follicles, it was clear that some individual follicles had enzyme activity whereas others did not. The substrate requirement in small follicles for half-maximum oestradiol biosynthesis (i.e. the apparent $K \mathrm{~m}$ value) was very high on Days -5 to 0 (521-1022 mM) whereas on Day +1 it was relatively low (27-37 mM). Furthermore, $<25 \%$ of all small healthy follicles on Days -4 and 0 had measureable aromatase activity whereas all the small and intermediate-sized follicles on Day +1 had some activity (Text-fig. 3). A major difference between follicles on Day +1 compared to Days -4 to 0 is that all follicles on Day +1 would have experienced the preovulatory surge of LH and FSH (see Hansel \& Convey, 1983, for review). Whilst the gonadotrophin surge may down-regulate aromatase activity in large follicles and initiate preovulatory luteinization (Dieleman, Kruip, Fontijne, de Jong \& van der Weyden, 1983), it may concomitantly have increased the oestrogen-secreting potential of the small healthy follicles by altering the kinetic properties of the aromatizing enzyme system. The thecae from the small follicles on Day +1 still retained their ability to respond steroidogenically to LH in vitro (data not shown), but it is not known whether the increased incidence of aromatase activity in follicles on Day +1 was due to increased exposure to $\mathrm{FSH}, \mathrm{LH}$ or androgen or any combination thereof.

Henderson et al. (1984) have shown that the theca interna from healthy and atretic follicles has specific $\mathrm{LH} / \mathrm{hCG}$ receptors and that the binding characteristics of these receptors do not change with increasing atresia. However, as large follicles degenerate from Grade la to $1 \mathrm{~b}$ or $2 \mathrm{a}$, the thecae internae were no longer capable of secreting androgen or progesterone in response to LH (see 'Results'; Henderson et al., 1984; McNatty et al., 1984a). In conjunction with this loss of steroidogenesis in thecal tissue there were significantly higher progesterone concentrations in follicular fluid together with significantly lower ( 30 -fold) oestradiol concentrations relative to those in dominant follicles (Table 2). Since small- and intermediate-sized as well as the large atretic follicles contained higher $(P<0.01)$ progesterone concentrations than healthy follicles of equivalent size, it seems reasonable to constatidat increased progesterone synthesis by granulosa cells is a common event during atresigsolicles. 
In contrast to the inability of $\mathrm{LH}$ to stimulate androgen synthesis in large atretic follicles, smallor intermediate-sized atretic follicles (Grades $1 \mathrm{~b}$ and $2 \mathrm{a}$ ) still retained a potential to synthesize androgen when stimulated by LH. Therefore, if all the healthy and many of the atretic follicles are capable of synthesizing androgen in response to LH, one could expect between 20 and 60 follicles ( $>2 \mathrm{~mm}$ diam.) per cow to secrete androgen in response to LH whereas only 1-3 would have the ability to metabolize the newly synthesized androgen to oestrogen. This finding may partly explain the extremely large variation in the concentrations of androstenedione in ovarian venous blood, the relatively high concentrations of androgen in small healthy and atretic follicles as well as the low concentrations of androgen in large healthy follicles (see also Wise et al., 1982).

In conclusion our data suggest that most, if not all, healthy follicles ( $\geqslant 2 \mathrm{~mm}$ diam.) and many atretic follicles are biochemically competent to secrete androstenedione in response to LH whereas only 1-3 follicles ( $\geqslant 5 \mathrm{~mm}$ diam.) per cow have granulosa cells capable of metabolizing androstenedione to oestrogen. The aromatizing enzyme complex seems to be highly variable in activity and perhaps even unstable. The absence of aromatase activity in large or intermediate healthy follicles may indicate one of the earliest signs of atresia. Therefore, an understanding of the factors regulating granulosa cell aromatizing activity may help to provide new insights into methods of enhancing the ovulation rate in cattle.

We thank the National Pituitary Agency, Maryland, U.S.A. for the supply of bovine and ovine pituitary hormones; Mr R. M. Goodwin, Mr H. H. Gwilliam and Mr I. C. Scott for monitoring oestrous activity; Miss N. Hudson, Mrs K. Ball and Mrs J. McDiarmid for assistance with surgery, blood sampling, steroid radioimmunoassays and animal care; Mr P. Smith for preparing the oocytes for histology; Mrs K. Mason for preparing the enzyme kinetics programme; and Mrs P. Cattermole for typing the manuscript.

\section{References}

Choudary, J.B., Gier, H.T. \& Marion, G.B. (1968) Cyclic changes in bovine vesicular follicles. J. Anim. Sci. 27, $468-474$.

Crabbe, M.B. (1982) An enzyme kinetics program for desk top computers. Comp. Biol. Med. 12, 263-283.

Dieleman, S.J., Kruip, Th.A.M., Fontijne, P., de Jong, W.H.R. \& van der Weyden, G.C. (1983) Changes in oestradiol, progesterone and testosterone concentrations in follicular fluid and in the micromorphology of preovulatory bovine follicles relative to the peak of luteinizing hormone. J. Endocr. 97, 31-42.

Dobson, H. \& Dean, P.D.G. (1974) Radioimmunoassay of oestrone, oestradiol- $17 \alpha$ and $-17 \beta$ in bovine plasma during the oestrous cycle and last stages of pregnancy. $J$. Endocr. 61, 479-486.

Donaldson, L. \& Hansel, W. (1965) Histological study of bovine corpora lutea. J. Dairy Sci. 48, 905-909.

England, B.G., Karavolas, H.J., Hauser, E.R. \& Casida, L.E. (1973) Ovarian follicular estrogens in Angus heifers. J. Anim. Sci. 37, 1176-1179.

Erickson, B.H. (1966) Development and senescence of the postnatal bovine ovary. J. Anim. Sci. 25, 800-805.

Genstat (1981) A General Statistical Program, ch. 8. Rothamsted Experimental Station, Herts, U.K.

Hansel, W. \& Convey, E.M. (1983) Physiology of the estrous cycle. J. Anim. Sci. 57, Suppl. 2, 404-424.

Henderson, K.M. \& Moon, Y.S. (1979) Luteinization of bovine granulosa cells and corpus luteum formation associated with loss of androgen aromatizing ability. J. Reprod. Fert. 56, 89-97.
Henderson, K.M., Kieboom, L.E., McNatty, K.P., Lun, S. \& Heath, D.A. (1984) ${ }^{125}$ I-hCG binding to bovine thecal tissue from healthy and atretic follicles. Molec. cell. Endocr. 34, 91-98.

Hillier, S.G. (1981) Regulation of follicular oestrogen biosynthesis : a survey of current concepts. J. Endocr. 89, $3 p-18 p$.

Ireland, J.J. \& Roche, J.F. (1983) Development of nonovulatory antral follicles in heifers: changes in steroids in follicular fluid and receptors for gonadotropins. Endocrinology 112, 150-156.

Ireland, J.J., Coulson, P.B. \& Murphree, R.L. (1979) Follicular development during four stages of the estrous cycle of beef cattle. J. Anim. Sci. 48, 12611269.

Kruip, Th.A.M. \& Dieleman, S.J. (1982) Macroscopic classification of bovine follicles and its validation by micromorphological and steroid-biochemical procedures. Reprod. Nutr. Dev. 22, 465-473.

Lemon, M. \& Saumande, J. (1974) The evolution of ovarian steroid hormones during luteolysis and folliculogenesis in the cow. In Ovarian Function, pp. 69-76. Eds T. K. A. B. Eskes, H. L. Houtzager \& E. V. van Hall. Excerpta Medica, Amsterdam.

Lunaas, T. (1964) Distribution of oestrone and oestradiol in the bovine ovary. Acta vet. scand. 5, 35-49.

Marion, G.B., Gier, H.T. \& Choudary, J.B. (1968) Micromorphology of the bovine ovarian follicular system. J. Anim. Sci. 27, 451-465.

Matton, P., Adelakoun, V., Couture, Y. \& Dufour, J.J. 
(1981) Growth and replacement of the bovine ovarian follicles during the estrous cycle. J. Anim. Sci. 52, 813-820.

McNatty, K.P. (1982) Ovarian follicular development from the onset of luteal regression in humans and sheep. In Follicular Maturation and Ovulation, pp. 117. Eds R. Rolland, E. V. van Hall, S. G. Hillier, K. P. McNatty \& J. Schoemaker. Excerpta Medica, Amsterdam.

McNatty, K.P., Gibb, M., Dobson, C., Thurley, D.C. \& Findlay, J.K. (1981) Changes in the concentrations of gonadotrophic and steroidal hormones in the antral fluid of ovarian follicles throughout the oestrous cycle of the sheep. Aust. J. biol. Sci. 34, 67-80.

McNatty, K.P., Gibb, M., Dobson, C., Ball, K., Coster, J., Heath, D. \& Thurley, D.C. (1982) Preovulatory follicular development in sheep treated with PMSG and/or prostaglandin. J. Reprod. Fert. 65, 111-123.

McNatty, K.P., Hillier, S.G., van den Boogaard, A.M.J., Trimbos-Kemper, T.C.M., Reichert, L.E. \& van Hall, E.V. (1983) Follicular development during the luteal phase of the human menstrual cycle. J. clin. Endocr. Metab. 56, 1022-1031.

McNatty, K.P., Heath, D.A., Lun, S., Fannin, J., McDiarmid, J.M. \& Henderson, K.M. (1984a) Steroidogenesis by bovine theca interna in an in vitro perifusion system. Biol. Reprod. 30, 159-170.

McNatty, K.P., Hudson, N.L., Henderson, K.M., Lun, S., Heath, D.A., Gibb, M., Ball, K., McDiarmid, J.M. \& Thurley, D.C. (1984b) Changes in gonadotrophin secretion and ovarian antral follicular activity in seasonally breeding sheep throughout the year. $J$. Reprod. Fert. 70, 309-321.

Merz, E.A., Hauser, E.R. \& England, B.G. (1981) Ovarian function in the cycling cow: relationship between gonadotrophin binding to theca and granulosa and steroidogenesis in individual follicles. $J$. Anim. Sci. 52, 1457-1468.

Moor, R.M., Hay, M.F., Dott, H. \& Cran, D.G. (1978) Macroscopic identification and steroidogenic func- tion of atretic follicles in sheep. $J$. Endocr. 77, 309318.

Peterson, A.J., Fairclough, R.J., Payne, E. \& Smith, J.F. (1975) Hormonal changes about bovine luteolysis. Prostaglandins 10, 675-684.

Peterson, A.J., Fairclough, R.J. \& Smith, J.F. (1978) Radioimmunoassay of androstenedione and testosterone in cow plasma at the time of luteolysis and oestrus. J. Reprod. Fert. 52, 127-129.

Priedkalns, C.D., Weber, A.F. \& Zemjanis, R. (1968) Qualitative and quantitative morphological studies of the cells of the membrana granulosa, theca interna and corpus luteum of the bovine ovary. Z. Zellforsch. mikrosk. Anat. 85, 501-520.

Rajakoski, E. (1960) The ovarian follicular system in sexually mature heifers with special reference to seasonal, cyclical, and left-right variations. Acta endocr., Copenh., Suppl. 52, 6-7.

Scaramuzzi, R.J., Tumbull, K.E. \& Nancarrow, C.D. (1980) Growth of Graafian follicles in cows following luteolysis induced by the prostaglandin $F_{2 \alpha}$ analogue, cloprostenol. Aust. J. biol. Sci. 33, 63-69.

Short, R.V. (1962) Steroid concentrations in normal follicular fluid and ovarian cyst fluid from cows. $J$. Reprod. Fert. 4, 27-45.

Staigmiller, R.B. \& England, B.G. (1982) Folliculogenesis in the bovine. Theriogenology 17, 43-52.

Staigmiller, R.B., England, B.G., Webb, R., Short, R.E. \& Bellows, R.A. (1982) Estrogen secretion and gonadotrophin binding by individual bovine follicles during estrus. J. Anim. Sci. 55, 1473-1482.

Thomeycroft, I.H. \& Stone, S.C. (1972) Radioimmunoassay of serum progesterone in women receiving oral contraceptives. Contraception 5, 129-146.

Wise, T.H., Caton, D., Thatcher, W.W., Lehrer, A.R. \& Fields, M.J. (1982) Androstenedione, dehydroepiandrosterone and testosterone in ovarian vein plasma and androstenedione in peripheral arterial plasma during the bovine oestrous cycle. J. Reprod. Fert. 66, $513-518$.

Received 6 December 1983 